\title{
Editorial
}

\section{Medical journals and cross-cultural research ethics}

Joan C. Bevan MD, * Donald R. Miller MD $\dagger$

Most biomedical journals, including the Canadian Journal of Anesthesia, embrace an international content. They compete to publish the most important and original scientific articles in their respective fields. In recent years, editors and reviewers have been confronted with increasingly complex ethical dilemmas when reviewing manuscripts reporting the results of international research. Challenges have emerged because manuscripts often originate in countries that have ethical criteria at variance from the principles and norms of the country of the journal to which they are submitted.

There is a trust relationship between editors and authors that clinical research will have been carried out in accordance with applicable research ethics guidelines. While authors are guided in the preparation and submission or their manuscripts by the "Information/ Instruction for Authors" posted on each journal's website, their application may vary depending on the policies of the Research Ethics Boards (REB), or local ethics review systems, where the research was conducted.

Recently, the Editorial Board of the Canadian Journal of Anesthesia had to make policy decisions regarding manuscripts that presented ethical issues. The Board had to decide upon the acceptability of retrospective studies involving chart reviews which had not received ethical approval. Such approval had not been made mandatory by the institutions from which the works originated. Furthermore, some countries do not seek written informed consent or document agreement to participate in randomized clinical trials. In some instances, only verbal consent is obtained, or consent is waived entirely. The difficulty arises in deciding when local cultural values are morally acceptable in the context of international research, or when they infringe basic human rights or inflict harms. In the unsettled and evolving international ethical and legal norms, editors have to make practical decisions on publication.

We present a discussion of the current and emerging challenges in cross-cultural research ethics that face authors, editors and readers of biomedical journals.

\section{Codes of ethical conduct for editors}

Most medical journals follow recommendations of the International Committee of Medical Journal Editors (ICMJE) Uniform Requirements for Manuscripts Submitted to Biomedical Journals. ${ }^{1}$ The current revision requires authors to adhere to ethical guidelines and gives editors "editorial freedom" to decide which manuscripts they will accept for publication. In the United Kingdom, the Committee on Publication Ethics $(\mathrm{COPE})^{2}$ is more specific, stating that "editors should ensure that research material they publish conforms to internationally accepted guidelines, including, for example, the Declaration of Helsinki. The research should, where appropriate, have been approved by an ethics committee". Editorial decisions on the ethics of publication can be particularly challenging in the context of cross-cultural research.

\section{Globalization of clinical trials}

Clinical research depends on the recruitment of human subjects for clinical trials. Pharmaceutical research had proceeded slowly until the 1950s and drugs were tested on federal prisoners. Regulations banned this practice in the United States by the 1970s and, for the next 20 years, investigational new drugs were tested in academic health centres. Typically, multicentre trials replaced single-centre trials, and a larger number of patients were studied. However, the sustained increase in demand for subjects could not be met in academic centres. Contract research organizations emerged,

From the Department of Anesthesia, * University of Toronto, Toronto; and the Editorial Office of the Canadian Journal of Anesthesia, $\uparrow$, Ottawa, Ontario, Canada.

Address correspondence to: Dr. Joan C. Bevan, University of Toronto, Department of Anesthesia, Room 126, FitzGerald Building, 150 College Street, Toronto, Ontario M5S 3E2, Canada. Phone: 416-978-4306; E-mail: joan.bevan@utoronto.ca 
and expedited the clinical trials needed for regulatory drug approvals by recruiting from the community, at a lower cost. The average length of cancer trials was shortened from seven to three years in the United Kindom. ${ }^{3}$ Pharmaceutical companies became multinational corporations and, by the early 1990s, drug development was a truly global enterprise. ${ }^{4}$

Competition for rapid recruitment of large numbers of human subjects into clinical trials became intense. After the International Conference of Harmonization (ICH) in 1996 and the subsequent European Union Directive in 2001, the Good Clinical Practice Guidelines (GCP) governing the conduct of international clinical trials were formulated. These included, for the first time, the admissibility of foreign-derived clinical data for regulatory approval of new drugs in the United States. ${ }^{5}$ Canada adopted the same policy in 2003. International recruitment now comes from countries in Eastern Europe, that provide little basic health care, or countries with enormous populations, like Brazil. Other countries that agreed to harmonization of drug testing, include Argentina, Brazil, Hungary, Mexico, Poland, Russia and Thailand. It is estimated that the number of subjects in international trials increased from 4,000 in 1995 to 400,000 in 1999. It is clear that the well-being and safety of patients depend upon the development and application of international research ethical guidelines.

\section{Regulation of international research}

Over the last 55 years, the governance of clinical research has advanced in accordance with changing perspectives on human rights. Standards in international research ethics in clinical trials were first addressed by the post-war Nuremberg Code in 1949. This made voluntary informed consent of an individual essential for research participation and required scientific justification for the study. The World Medical Association's (WMA) Declaration of Helsinki, adopted in 1964 and revised in 2000, recognized the need to advance medical progress by properly conducted research, but binds the physician to first safeguarding a person's health. In 1982, the World Health Organization (WHO), the Council of the International Organization of Medical Societies (CIOMS) and European guidelines agreed on the requirement for research protocols to be approved by a research ethics committee. The Department of Health in the United Kingdom formalized the need for ethics review in 1991. Since then, REB approval for clinical studies has been generally accepted as a prerequisite to publication of results in an academic journal.

The current ICH-GCP guidelines for multinational clinical trials set standards for testing the safety of experimental drugs, while aiming to facilitate medical discovery and protect clinical trial participants. It describes GCP as "An international ethical and scientific quality standard for designing, conducting and reporting clinical trials that involve the participation of human subjects....provides public assurance that the rights, safety and well-being of trial subjects are protected, consistent with the Declaration of Helsinki and that clinical data are credible". In North America, the United States has a strong research regulatory framework which oversees compliance with the federal codes that protect research participants. Equivalent ethical principles are followed in Canada under the 1998-2004 Tri-Council Policy Statement (TCPS): Ethical Conduct for Research Involving Humans subjects. ${ }^{6}$

Ongoing research after completion of the Human Genome Project, in 2003, raises difficult ethical, legal and social issues. ${ }^{7}$ The Council of Europe recommended that the Human Genome should be considered as "The common heritage of humanity" that is a global public good: a concept that relies on international agreement. A consensus is emerging on the norms for use of clinical and research samples and bio-banking. ${ }^{8}$ The United Nations Educational, Scientific and Cultural Organization (UNESCO) published declarations in 1997 and 2003, with statements by the Human Genome Organization (HUGO) and the Council for International Organization of Medical Sciences in 1998 and 2002. They recognize that consent is not always practical, or necessary, for the use of anonymised samples and data (archival material, left-over tissue from clinical samples, post-mortem samples or previously obtained research samples), but emphasize the need for REB approval.

Recent international debate concluded that it was "Opportune and desirable to set universal standards in the field of bioethics with due regard for human dignity and human rights and freedoms, in the spirit of cultural pluralism inherent in bioethics". The UNESCO International Bioethics Committee then examined bioethical issues that relate to scientific experimentation in the international setting. They defined bioethics as "Systematic pluralistic ethical issues in life and social sciences in human beings and related to the biosphere" and issued a preliminary Draft Declaration on Universal Norms in Bioethics ${ }^{9}$ on February 9, 2005 that sets global guidelines for shared ethical values.

\section{Issues in cross-cultural research ethics}

Globalization of clinical research has transferred drug trials from richer parts of the world, where the potential for commercialization is greatest, to resource-poor 
nations. Thus, researchers may be working across national boundaries in countries with different socioeconomic standards. Recruitment from politically and economically unstable countries, that lack medical services means that patients are vulnerable and participate willingly, even to obtain temporary health care benefit for the duration of the trial. The main goal of recruitment into clinical trials is not the welfare of the human participants: they are a source of valuable "treatment naive" subjects. Ethical standards differ in cultures with different collective values. ${ }^{10}$ Westernized ethics are based on respect for individual autonomy and liberalism, emphasizing voluntary, informed consent for research participants, while many cultures value community involvement in decision making for the common good. Collaborative cross-cultural research generates issues related to ethics committee approval, informed consent, placebo-controlled trials and standards of medical care.

International research protocols have to receive ethical review board approval in both jurisdictions, and satisfy the ethics of both countries. However, there are increasing concerns that researchers have disregarded the basic rights of some research subjects, and that governments have been complicit in facilitating recruitment. The first suit for damages against a pharmaceutical company, for medical experimentation on foreign subjects without their consent, has been brought against a United States-based pharmaceutical company by 30 Nigerian families. During an outbreak of bacterial meningitis in Kano in 1996, they gave children an experimental antibiotic, Trovan, which was implicated in causing deaths, paralysis and deafness. The unapproved drug use had been authorized by the United States Department of Food and Drug Administration on humanitarian grounds, and the protocol received sparse review in the host country. Existing international research ethics codes were violated and children were deprived of the local standard of care, a less expensive antibiotic, without parental consent.

Voluntary informed consent is an almost exclusively Westernized concept. Moral absolutism is the view that ethics cannot be changed, regardless of circumstances. Moral relativism relates morality to the context of local culture, and reasons that abstract ethical principles can be applied in the local ethos. Respect for persons means treating them within their own cultural norms. Obtaining consent depends on understanding the perceptions of others and applying their own standards to the process. Many cultures value the social aspects of diseases that connect individuals, health and illness, with moral, religious, political and economic realities. ${ }^{7,10}$ The concept of person relates to family and other people: an interaction between individuals and their social and spiritual environment with valueladen norms. Respect for a participant's autonomy may mean respecting traditional values, with deference to family or community leaders for consent to research participation. Discussions with community elders and family heads may facilitate recruitment of individuals, but written documentation is not always practical in largely illiterate societies.

Attempts to prevent the exploitation of distinct communities for research purposes are still limited. Ethnic groups and aboriginal communities became targets for genetic research into diseases, or to follow ancient migration patterns, before adequate protection for participants was developed. The case of the Nuu-chah nulth tribes, on the West coast of Vancouver Island, began in 1982 when their blood samples were taken for a genetic study of arthritis. The samples were then used without consent, leading to publication of a paper on 'mitochondrial diversity' in the Proceedings of the National Academy of Sciences in 1991. The Nuu-chah nulth are seeking ownership of the samples and formed their own REB, in 2003, to review any future research in their community. Some guidance on research involving aboriginal peoples is given in TCPS, and the Australian National Health and Medical Research Council guidelines for research ethics in Torres Strait Islander Research $(1991)^{11}$ are comprehensive. These guidelines encourage researchers to be sensitive to cultural needs, and initiate community consultations when developing protocols, through recruitment and data collection phases until the publication of study results.

The African placebo-controlled study of the perinatal prevention of transmission of HIV by short therapy azothiaprine, in 1994, started an intense debate on placebo use. This led to the 2000 amendment of the Declaration of Helsinki to require "the use of the best current prophylactic, diagnostic and therapeutic methods available worldwide" and allowing placebo controls only if no such alternatives were available. Opponents to this provision fought for the continued use of placebo-controlled trials, citing the ICH-GCP as the authority that stated: "Acceptability of placebo use could depend on the specific trial design and population chosen". Arguments against the amendment, in favour of placebo use prevailed: that there was never provision for post-trial access to medication, all patients would be denied treatment if trials did not occur, and that medication for the duration of the trial was better than none at all. The amendment was retracted to reflect a weaker requirement, creating a variable ethical standard for medical 'standard 
of care'. The debate is not settled: ethical absolutism dictates that patients in the control group should receive the best treatment available anywhere in the world, whereas ethical relativism allows the use of the equivalent, or best locally available treatment, which could be 'no treatment'.

\section{Changing journal policies}

Cross-cultural research has to comply with the spirit of international ethical guidelines to protect research subjects while encouraging international collaborations. Even though local ethics review is not always formalized and consent procedures may be modified or waived in some circumstances, the research may be ethical in its cultural context, and the manuscripts may be accepted for publication. The Editor-in-Chief and Editorial Board of the Canadian Journal of Anesthesia take the issue of the ethical conduct of human clinical trials very seriously. Our consent policies were updated in January 2005 in response to evolving ethical and legal norms, to require consent for publication of case reports/case series, regardless of the country from which the manuscript was submitted. We favour policies that have sufficient flexibility to respond to continually changing attitudes worldwide.

The updated statement regarding ethical conduct for human studies appears below, and is referenced under the Information for Authors at the journal website at www.cja-jca.org.

"Manuscripts describing investigations carried out in humans will not be accepted for publication unless the study was approved by, and carried out according to instructions of the author's institutional Human Investigations Committee or the REB. A statement concerning REB approval and consent procedures must appear at the beginning of the Methods section. Any systematic data gathering efforts in patients or volunteers must also be approved by a REB or adhere to local/national regulations. Patient consent is also requires for publication of personal information in Case Reports/Case series in accordance with local institutional guidelines. Lack of appropriate consent or documentation may be grounds for rejection."

\section{Les revues médicales et les normes déontolo giques transculturelles}

La plupart des revues médicales, dont le Journal canadien d'anesthésie, présentent un contenu international. Elles sont en compétition pour publier les articles scientifiques les plus importants et les plus originaux dans leur domaine respectif. Au cours des dernières années, des rédacteurs et des réviseurs ont été confrontés à des dilemmes éthiques de plus en plus complexes lors de l'examen de manuscrits rapportant les résultats de recherches internationales. Les manuscrits venant de pays étrangers, où les critères éthiques sont différents, soulèvent bien des questions.

Selon le lien de confiance qui existe entre les rédacteurs et les auteurs, on suppose que la recherche clinique a été menée en suivant les normes d'éthique applicables. Les auteurs sont guidés dans la préparation et la présentation de leur manuscrit par les «Directives aux auteurs» affichées sur le site Web de chaque revue, mais leur application peut dépendre des politiques du Comité d'éthique de la recherche (CER) ou des systèmes d'examen déontologique locaux.

Récemment le Comité de rédaction du Journal canadien d'anesthésie a dû émettre des décisions de principe sur les manuscrits qui présentent des enjeux éthiques. Le comité a eu à décider de l'acceptabilité d'études rétrospectives, comportant l'examen de dossiers, qui n'avaient pas reçu d'approbation d'un comité d'éthique. L'autorisation n'avait pas été rendue obligatoire par les institutions d'où provenaient les travaux. De plus, dans certains pays, on ne fait pas signer de consentement à l'approbation du document de participation à des essais cliniques randomisés. Parfois, seul un consentement verbal suffit ou il n'y a aucun consentement requis. La difficulté surgit quand il faut décider si les valeurs culturelles locales sont moralement acceptables dans le contexte de la recherche internationale ou si elles violent les droits humains fondamentaux ou portent préjudice. Dans le contexte de normes éthiques et juridiques internationales, changeantes et incertaines, les rédacteurs doivent prendre des décisions pratiques pour la publication.

Nous présentons une réflexion sur les défis actuels et émergeants de l'éthique de la recherche transculturelle pour les auteurs, rédacteurs et lecteurs de revues biomédicales. 
Le code d'éthique des rédacteurs

La majorité des revues médicales suivent les recommandations de l'International Committee of Medical Journal Editors (ICMJE) publiées dans Uniform Requirements for Manuscripts Submitted to Biomedical Journals. ${ }^{1}$ La version actuelle demande aux auteurs d'observer le guide d'éthique et accorde la «liberté aux rédacteurs» de décider des manuscrits à publier. Au Royaume-Uni, le Committee on Publication Ethics $(\mathrm{COPE})^{2}$ est plus spécifique, déclarant que «les rédacteurs doivent s'assurer que les documents de recherche qu'ils publient sont conformes aux normes internationales, y compris, par exemple, à la Déclaration d'Helsinki. La recherche doit, s'il y a lieu, avoir été approuvée par un comité d'éthique». Les décisions de la direction portant sur l'éthique des publications peuvent être particulièrement complexes dans le contexte d'une recherche transculturelle.

\section{La mondialisation des essais cliniques}

La recherche clinique repose sur le recrutement de sujets humains pour des essais cliniques. La recherche pharmaceutique avait évolué lentement jusqu'aux années 1950 et des médicaments avaient été testés sur des prisonniers fédéraux. Une réglementation a banni cette pratique aux États-Unis dans les années 1970 et, pendant les 20 années suivantes, l'expérimentation des nouveaux médicaments a été faite dans des centres de santé universitaires. En général, les essais sont réalisés dans plusieurs centres, non plus un seul, et de nombreux patients sont étudiés. La demande grandissante de sujets ne peut toutefois être satisfaite dans les centres universitaires. Des sociétés de recherche sous contrat émergent donc, qui accélèrent les essais cliniques nécessaires à l'approbation réglementée des médicaments en recrutant dans la communauté à un moindre coût. La durée moyenne des essais sur le cancer passe de sept à trois ans au Royaume-Uni. ${ }^{3}$ Les compagnies pharmaceutiques deviennent des multinationales et, dans les années 1990, le développement des médicaments est une réelle entreprise mondiale. ${ }^{4}$

Le recrutement rapide de grands nombres de sujets humains pour des essais cliniques est l'objet d'une intense compétition. Après la Conférence internationale sur l'harmonisation (CIH) en 1996 et les Directives de l'Union européenne en 2001, les Bonnes pratiques cliniques (BPC) sur l'éthique des essais cliniques internationaux sont formulées. Est incluse, pour la première fois, l'admissibilité de données cliniques venant de l'étranger pour l'approbation de nouveaux médicaments aux États-Unis. ${ }^{5}$ Le Canada adopte cette politique en 2003. Le recrutement international provient maintenant de pays d'Europe de
l'Est, qui offrent peu de services de santé de base, ou de pays très populeux comme le Brésil. Ont aussi accepté l'harmonisation des essais de médicaments, l'Argentine, le Brésil, la Hongrie, le Mexique, la Pologne, la Russie et la Thaillande. On estime que le nombre de sujets participant à des études internationales est passé de 4000 en 1995 à 400000 en 1999. Le bien-être et la sécurité des sujets dépendent donc de l'élaboration et de l'application d'un code d'éthique en recherche internationale.

\section{Réglementation de la recherche internationale}

Pendant les 55 dernières années, la gouvernance de la recherche clinique a évolué avec les perspectives changeantes sur les droits humains. Les normes d'éthique de la recherche internationale dans les essais cliniques ont d'abord été inscrites dans le Code de Nuremberg, en 1949. Le consentement libre et éclairé d'un individu devenait essentiel pour participer à une recherche et la justification scientifique était exigée. La Déclaration d'Helsinki de l'Association médicale mondiale (AMM), adoptée en 1964 et révisée en 2000 , a reconnu qu'il fallait accélérer le progrès médical en menant la recherche avec efficacité, mais a obligé le médecin à préserver d'abord la santé des sujets. En 1982, l'Organisation mondiale de la santé (OMS), le Conseil des organisations internationales des sciences médicales (CIOMS) et les directives européennes s'entendaient pour exiger l'approbation des protocoles de recherche par un comité d'éthique de la recherche (CER). Le Department of Health du Royaume-Uni a officialisé cette exigence en 1991. Depuis, l'approbation du CER pour les études cliniques est, en général, acceptée comme pré-requis à la publication de résultats dans une revue scientifique.

Les directives actuelles de la CIH-BPC pour les essais cliniques multinationaux établissent des normes pour vérifier la sécurité des médicaments expérimentaux, tout en cherchant à faciliter les découvertes médicales et à protéger les participants. On y décrit les BPC comme «Une norme de qualité éthique et scientifique internationale s'appliquant à la conception et à la réalisation d'essais auxquels participent des sujets humains ainsi qu'à l'enregistrement et à la présentation des données relatives à ces essais.... garantit au public que les droits, l'innocuité et le bienêtre des sujets participant à l'essai sont protégés, conformément aux principes découlant de la Déclaration d'Helsinki, et que les données sur les essais cliniques sont fiables». En Amérique du Nord, les États-Unis ont un solide cadre réglementaire pour la recherche, lequel vérifie s'il y a conformité aux codes fédéraux qui protègent les participants à la recherche. Des principes 
éthiques semblables sont suivis au Canada et présentés dans l'Énoncé politique des trois conseils (EPTC) 1998-2004: Éthique de la recherche avec des êtres humains. ${ }^{6}$

Les recherches entreprises en 2003, au terme du Projet de génome humain, soulèvent de sérieuses questions éthiques, juridiques et sociales. ${ }^{7} \mathrm{Le}$ Conseil de l'Europe a recommandé que le Génome humain soit considéré comme «le patrimoine commun de l'humanité», c'est-à-dire un bien public mondial : un concept qui relève d'un accord international. Un consensus se dessine sur les normes entourant l'usage d'échantillons cliniques et expérimentaux et sur le biostockage. ${ }^{8}$ L'Organisation des Nations Unies pour l'éducation, la science et la culture (UNESCO) a publié des déclarations en 1997 et en 2003 et des mémoires produits par la Human Genome Organization (HUGO) et le Conseil des organisations internationales des sciences médicales en 1998 et 2002. Ils ont reconnu que le consentement n'est pas toujours pratique, ou nécessaire, pour l'usage d'échantillons et de données anonymes (matériel d'archive, échantillons cliniques de tissus non utilisés, échantillons obtenus lors d'autopsie ou de recherches antérieures), mais ils ont insisté sur la nécessité de l'approbation des recherches par les CER.

Lors d'un récent débat international, on a conclu qu'il était «opportun et souhaitable de définir des normes universelles en matière de bioéthique dans le respect de la dignité humaine et des droits et des libertés de la personne, dans l'esprit du pluralisme culturel de la bioéthique». Le Comité international de bioéthique de l'UNESCO a ensuite examiné les enjeux bioéthiques reliés à l'expérimentation scientifique dans le cadre international. Il a défini la bioéthique comme «Des enjeux éthiques pluralistes et systématiques en sciences de la vie et en sciences humaines en relation avec la biosphère» et il a publié, le 9 février 2005, un Avant-projet de déclaration relative à des normes universelles en matière de bioéthique ${ }^{9}$ qui définit les grandes lignes des valeurs éthiques communes.

\section{Enjeux des normes d'éthique transculturelles}

La mondialisation de la recherche clinique a déplacé les études sur les médicaments des pays les plus riches, où le potentiel de commercialisation est le plus grand, vers les pays pauvres. Ainsi, les chercheurs peuvent travailler au-delà des frontières nationales dans des pays aux niveaux socio-économiques différents. Le recrutement dans des pays instables au plan politique et économique, et qui manquent de services médicaux, implique des patients vulnérables qui participent volontiers même si ce n'est que pour bénéficier de soins de santé le temps de l'étude. L'objectif principal du recrutement n'est pas le bien-être des participants : ils ne sont qu'une source valable de sujets «novices au traitement». Les critères éthiques varient avec les valeurs collectives des différentes cultures. ${ }^{10}$ L'éthique occidentale est fondée sur le respect de l'autonomie et du libéralisme individuel, elle met l'accent sur le consentement libre et éclairé des participants à la recherche tandis que de nombreuses cultures valorisent l'engagement communautaire dans la prise de décision pour le bien commun. La recherche de collaboration transculturelle soulève des questions reliées à l'approbation par le comité d'éthique, au consentement éclairé, aux études contrôlées contre placebo et aux normes des soins médicaux.

Les protocoles de recherche internationale doivent être approuvés par le comité d'éthique des deux autorités et répondre à l'éthique des deux pays. Cependant, on s'inquiète de plus en plus du fait que les chercheurs ne tiennent pas compte des droits fondamentaux de certains participants et que les gouvernements soient complices en facilitant le recrutement. La première poursuite pour dommages a eu lieu dans le cadre d'une expérimentation faite sur des sujets étrangers, sans leur consentement. Elle et a été engagée contre une compagnie pharmaceutique basée aux États-Unis par 30 familles nigérianes. Pendant une flambée de méningite bactérienne à Kano en 1996, on a donné aux enfants un antibiotique expérimental, le Trovan, qui a causé des décès, de la paralysie et de la surdité. L'usage non approuvé du médicament avait été autorisé par le Department of Food and Drug Administration des États-Unis pour des raisons humanitaires et le protocole n'avait reçu qu'une révision sommaire dans le pays hôte. Les codes d'éthique existants pour la recherche internationale ont été violés et les enfants privés des soins locaux habituels, en l'occurrence un antibiotique moins cher, sans le consentement des parents.

Le consentement libre et éclairé est un concept presque exclusivement occidental. L'absolutisme moral veut que l'éthique ne puisse être changée, peu importe les circonstances. Le relativisme moral établit un rapport entre la moralité et le contexte de la culture locale, ainsi que les raisons qui justifient l'application de principes déontologiques abstraits à l'ethos local. Le respect pour les personnes implique de les traiter selon les normes de leur culture propre. L'obtention du consentement s'appuie sur ce qu'on sait des perceptions des autres et sur l'application de leurs propres normes au processus. De nombreuses cultures s'attachent aux aspects sociaux des affections qui relient les individus, la santé et la maladie avec les réalités morales, 
religieuses, politiques et économiques. ${ }^{7,10}$ Le concept de personne se rapporte à la famille et aux autres : une interaction entre les individus et l'environnement social et spirituel dont les normes sont porteuses de valeurs. Respecter l'autonomie d'un participant pourrait vouloir dire respecter les valeurs traditionnelles en tenant compte du chef de la famille ou de la communauté pour obtenir le consentement à participer à une recherche. Des rencontres avec les aînés de la communauté et les chefs de famille peuvent faciliter le recrutement des participants, car la documentation écrite est rarement pratique dans des sociétés largement analphabètes.

Les interventions pour prévenir l'exploitation de certaines communautés dans des buts de recherche sont encore limitées. Des groupes ethniques et des communautés autochtones sont devenus la cible des recherches génétiques sur les maladies ou sur le devenir d'anciens modèles de migration avant qu'une protection adéquate des participants ne soit développée. Le cas des tribus Nuu-chah nulth de la côte ouest de l'île de Vancouver a commencé en 1982 alors que des échantillons sanguins leur ont été prélevés pour une étude génétique de l'arthrite. Les échantillons ont été ensuite utilisés sans leur consentement pour publier un article sur «la diversité mitochondriale» dans Proceedings of the National Academy of Sciences en 1991. Les Nuu-chah nulth tentent d'obtenir la propriété des échantillons et ils ont formé leur CER en 2003 pour reconsidérer toute nouvelle recherche dans leur communauté. Certains conseils sur la recherche auprès des peuples autochtones sont présentés dans l'EPTC (Énoncé de politique des trois Conseils) et détaillés dans les Australian National Health and Medical Research Council guidelines for research ethics in Torres Strait Islander Research (1991). ${ }^{11}$ Ces recommandations encouragent les chercheurs à être sensible aux besoins culturels, et à consulter la communauté quand des protocoles sont élaborés, pendant le recrutement et la collecte de données jusqu'à la publication des résultats de l'étude.

L'essai africain contrôlé contre placebo sur la prévention périnatale de la transmission du VIH par l'azothiaprine, en 1994, a suscité un vif débat sur l'usage du placebo. Il a conduit, en 2000, à un amendement à la Déclaration d'Helsinki pour exiger «l'utilisation des meilleures méthodes prophylactiques, diagnostiques et thérapeutiques actuellement disponibles à travers le monde» et pour permettre les contrôles par placebo seulement si aucune solution de rechange n'existe. Les opposants à cette mesure ont mené une bataille pour continuer d'utiliser les essais contrôlés, citant la CIH-BPC comme l'autorité qui avait déclaré : "L'acceptabilité de l'usage du placebo pourrait dépendre de l'organisation spécifique de l'étude et de la population choisie». Les arguments en faveur du placebo, ont prévalu : il n'y avait jamais eu de disposition concernant l'accès aux médicaments après l'étude, tous les patients seraient privés de traitements si les essais n'avaient pas lieu et tout médicament utilisé seulement pour la durée de l'expérience était mieux que rien. L'amendement a été retiré et remplacé par une exigence plus modeste, créant un niveau d'éthique variable pour «les normes de soins» médicaux. Le débat n'est pas clos: l'absolutisme éthique commande que les patients témoins reçoivent le meilleur traitement disponible dans le monde, tandis que le relativisme éthique permet l'usage d'un équivalent ou du meilleur traitement local existant, qui pourrait être «l'absence de traitement».

\section{La nouvelle politique du journal}

La recherche transculturelle doit respecter l'esprit $\mathrm{du}$ guide d'éthique international pour protéger les participants aux recherches tout en encourageant les collaborations internationales. Même si l'examen déontologique local n'est pas toujours officialisé et si les procédures pour obtenir le consentement peuvent varier ou être abandonnées dans certaines circonstances, la recherche peut être éthique dans son contexte culturel et les manuscrits acceptés pour publication. Le rédacteur en chef et le comité de rédaction du Journal canadien d'anesthésie ont pris très au sérieux la question de l'éthique des essais cliniques chez l'humain. Nos politiques de consentement ont été mises à jour en janvier 2005, en réponse aux changements dans les normes éthiques et juridiques, pour exiger le consentement à la publication de présentation /de séries de cas, sans égard au pays duquel provient le manuscrit. Nous favorisons les politiques qui ont assez de flexibilité pour s'adapter à l'évolution des changements d'attitude à travers le monde.

La plus récente recommandation sur l'éthique en recherche avec des humains est énoncée plus bas et apparait dans les directives aux auteurs sur le site Web du journal à www.cja-jca.org.

«Les manuscrits décrivant les résultats d'une recherche effectuée chez les humains ne seront pas publiés sans que l'étude ait été approuvée par le comité de recherche sur les humains ou le comité d'éthique de la recherche (CER) de l'institution où travaillent les auteurs, et conduite en conformité avec les directives de ce comité. Les auteurs doivent indiquer, au début de la section Méthode, si le CER a approuvé l'étude et comment le consentement des sujets a été obtenu. Toute collecte systématique de données chez 
des malades ou volontaires sains devra également avoir été approuvée par un CER ou se conformer à la réglementation locale/nationale. La publication de renseignements personnels dans le cadre d'une présentation/série de cas requiert également le consentement du ou des sujet(s), en accord avec les normes institutionnelles locales. L'absence de consentement ou de sa documentation pourra justifier le rejet du manuscrit».

\section{References}

1 International Committee of Medical Journal Editors. Uniform requirements for manuscripts submitted to biomedical journals: writing and editing for biomedical publication. Updated October 2004. Available from URL; http://www.icmje.org (site accessed July 4, 2005).

2 Committee on Publication Ethics (COPE). A code of conduct for editors of biomedical journals. Available from URL; http://www.publicationethics.org.uk/ guidelines/code (site accessed July 4, 2005).

3 Vale C, Stewart L, Tierney J; UK Coordinating Committee for Cancer Research National Register of Cancer. Trends in UK cancer trials: results from the UK Coordinating Committee for Cancer Research National Register of Cancer Trials. Br J Cancer 2005; 92: 811-4.

4 Petryna $A$. Ethical variability: drug development and globalizing clinical trials. American Ethnologist 2005; 32: 183-97.

5 Clinical Trials Directive (2001/20/EC) 2001.

Directive of the European Parliament and of the Council of the approximation of the laws, regulations and administrative provisions of the Member States relating to the implementation of Good Clinical Practice in the conduct of clinical trials on medicinal products for human use. Available from URL; http:// medicines.mhra.gov.uk/ourwork/licensingmeds/ types/clintrialdir.htm (site accessed July 4, 2005).

6 Government of Canada. Tri-Council Policy Statement: Ethical Conduct for Research Involving Humans (1998 updated 2004). Available from URL; http:// www.ncehr-cnerh.org/english/code_2/ (site accessed July 4, 2005).

7 Benatar SR. Towards progress in resolving dilemmas in international research ethics. J Law Med Ethics 2004; 32: 574-82.

8 Knoppers BM. Biobanking: international norms. J Law Med Ethics 2005; 33: 7-14.

9 United Nations Educational, Scientific and Cultural Organization (UNESCO) International Bioethics Committee (IBC). Preliminary draft declaration on universal norms on bioethics (February 9, 2005).
Available from URL; http://www.portal.unesco. org/shs/en/ev.php-URL_ID=1883\&URL_DO=DO_ TOPIC\&URL_SECTION=201.html (site accessed July 4, 2005).

10 Bowman $K$. What are the limits of bioethics in a culturally pluralistic society? J Law Med Ethics 2004; 32: 664-9.

11 National Health and Medical Research Council (NHMRC). Investing in Australia's health. Values and ethics: guidelines for ethical conduct in Aboriginal and Torres Strait Islander health research. 2003; section 2.2: 8-9. Available from URL; http://www.nhmrc. gov.au/publications/synopses/e52syn.htm (site accessed July 4, 2005). 